Editorial

\title{
Treatment without touch neither cures disease nor heals mind!
}

Volume 8 Issue I - 2017

\section{Editorial}

The motto of modern treatment is "High tech and high touch". Acknowledging advances of medical technology requires the most talented academics to be in the medical profession. Moreover, hospital setups are technologically well equipped to ensure the hightech approach of the profession. However, what about the high touch part of it? High touch is not only the robust physical touch or the most delicate touch with a scalpel. It is also about the emotional and empathetic touch! Should there not be clinical psychologist involved in the selection process of our future medical professionals to ascertain if they possess empathetic and compassionate qualities? Empathy is an ethical obligation of health care professionals towards patients. The Society of General Internal Medicine (SGIM) defined clinical empathy as "the act of correctly acknowledging the emotional state of another without experiencing that state oneself". ${ }^{1}$ There is a good correlation between physician empathy and patient satisfaction and a direct positive relationship with strengthening patient enablement. Empathy lowers patients' anxiety and distress and delivers significantly better clinical outcomes. ${ }^{2}$ In society, being a doctor is physically and emotionally demanding. There is good evidence to show that doctors are at higher risk of stress than the general population resulting in depression, burnout and mental health problems. Will it be fair to forget, healing the healers? $?^{3}$ As per medical ethics, it is the duty of a healthcare practitioner to treat his/her patient kindly, justly and attentively in all conditions. ${ }^{4}$ All major religious scriptures say, "Serving mankind is like serving God". ${ }^{5}$ Health care professionals must be Just, Kind, and Attentive to the patient regardless of whether rich or poor. ${ }^{6}$ In doing so, all holy books Quran, Bible and Torah mentioned that he who work just \& ethically will be rewarded. ${ }^{7}$ It is important to understand that the heart and mind work interchangeably between both the soul and spirit. They [the heart and mind] are neither exclusive nor inclusive to either one. ${ }^{8}$ According to unification theory, body, mind and soul are together. Treating only the physical features of the body, ignoring the mind and soul can one really provide total care of the patients? ${ }^{9}$

\section{Acknowledgements}

Author is expressing his gratitude to Brain Lynch, Limerick, Ireland for editing and providing valuable ideas.

\section{Conflicts of interest}

The author declare that there is no conflict of interest.

\author{
Azad Abdul Kalam \\ Department of Anesthesia, Combined Military Hospital, Dhaka, \\ Bangladesh \\ Correspondence: Azad Abdul Kalam, Department of \\ Anesthesia, Combined Military Hospital, Dhaka, Bangladesh, \\ Email azad100864@gmail.com \\ Received: May 19, 2017 | Published: May 24, 2017
}

\section{References}

1. Bhautesh Dinesh Jani, David N Blane, Stewart W Mercer. The Role of Empathy in Therapy and the Physician-Patient Relationship. Forsch Komplementmed. 2012;19(5):252-257.

2. Frans Derksen, Jozien Bensing, Antoine Lagro-Janssen. Effectiveness of empathy in general practice: a systematic review. Br J Gen Pract. 2013;63(606):16-84.

3. Josephine GWS Wong. Doctors and Stress. Medical Bulletin. 2008;13(6):4-7.

4. Vittoriana Crisera. Code of Ethics forHealthcare Practitioners. The Saudi Commission for Health Specialties Department of Medical Education \& Postgraduate Studies. Saudi Commission for Health Specialties, Riyadh, Saudi Arabia. 2014:1-60.

5. Sharif SM. Hadith. 1990(4).

6. The Glorious Qur'an, Chapter 04, Verse 135 \& Chapter 17, Verse 28 \& Chapter 16, Verse 90.

7. The Glorious Qur'an, Chapter 17, Verse 09.

8. Web:https://melchizedekschool.files.wordpress.com/2011/10/dividing the_human_spirit_soul_and_body.pdf

9. Zhi Gang Sha, Rulin Xiu Dr. Grand Unification Theory and Practice for Healing, Rejuvenation, Longevity, and Immortality. Benbella Books, Dallas, Texas. 2014 